\title{
Recensão/Review
}

\section{Aryon Dall'Igna Rodrigues, 2010, 'Tupí, tupinambá, línguas gerais e português do Brasil'. In: Volker Noll e Wolf Dietrich (orgs.), O português e o tupí no Brasil. São Paulo: Contexto:27-47.}

Jorge Domingues Lopes ${ }^{1}$

O artigo "Tupí, tupinambá, línguas gerais e português do Brasil”, de Aryon D. Rodrigues, professor aposentado da Universidade de Campinas, professor Emérito da UnB e um dos mais importantes pesquisadores das línguas indígenas brasileiras, busca contextualizar linguística e historicamente os termos tupí e tupinambá, a fim de estabelecer os limites exatos de seu uso, além de traçar os laços entre essas línguas e as línguas gerais e o português do Brasil.

Ao tratar neste artigo das duas línguas indígenas mais faladas no Brasil, principalmente no início da colonização do país, retoma e amplia o material dos dois primeiros capítulos da obra "Línguas Brasileiras: para o conhecimento das línguas indígenas" (Rodrigues 1986:17-39), conduzindo tanto o leitor iniciado no domínio da Linguística quanto o leitor leigo a desfazer confusões terminológicas acerca do uso do termo tupí no contexto brasileiro.

Dividido em seis partes, o texto inicia com a busca das primeiras referências relacionadas ao termo tupí, ainda no século XVI, principalmente nas obras dos jesuítas, dentre os quais se destaca José de Anchieta, autor da primeira gramática de uma língua brasileira. Além disso, o autor procura evidências que demonstrem a percepção, já naquela época, da existência das duas línguas, a dos tamoios e a dos tupiniquins. Assim, para estabelecer quais teriam sido as fronteiras linguísticas de cada grupo, parte da análise linguístico-comparativa dos registros remanescentes daquele período, ao mesmo tempo em que apresenta abundante bibliografia sobre aquelas línguas. Observa que, até determinado momento, não se fazia uma

\footnotetext{
' Doutorando em Linguística, Laboratório de Línguas Indígenas (LALI), Universidade de Brasília.
} 
separação nítida entre o tupí e o tupinambá, os quais eram conhecidos apenas pela denominação "língua brasílica".

Já na segunda parte do artigo, Rodrigues especializa ainda mais a distinção entre os termos tupí e tupinambá, situando-os, enquanto línguas, na mesma família linguística, ou seja, a família Tupí-Guaraní. Em seguida, prossegue sua busca "etimológica" em obras de autores dos séculos XVIII e XIX, e cita dois trabalhos relevantes nesse contexto: o de Martius, de 1863-1867, que apresentou "o primeiro ensaio de classificação dos povos indígenas do Brasil", identificando um grupo indígena ao qual denominou "tupis e guaranis"; e o de Magalhães (1876), "que empregou como sinônimos os termos Língua Geral, Tupí (vivo) e Nheengatu". Finda esta parte lembrando que o uso do termo tupinambá é relativamente recente e bastante restrito ao âmbito dos trabalhos da Linguística e da Antropologia.

Além desta discussão em torno da origem e uso dos termos tupí e tupinambá, o artigo trata dos contatos linguísticos que culminaram com empréstimos linguísticos para o português do Brasil. A título de exemplo, apresenta algumas dezenas de palavras ou expressões designativas de nomes de animais e de vegetais, topônimos, nomes comuns e verbos.

A quarta parte do artigo é dedicada à descrição da formação das línguas gerais, a paulista (LGP) e a amazônica (LGA), enquanto resultantes dos contatos entre os indígenas, originalmente falantes do tupí e do tupinambá, e os não-índios, falantes, em sua maioria, do português. Demonstra o difícil percurso histórico que os falantes da LGA atravessaram, na $1^{\mathrm{a}}$ metade do século XIX, durante o movimento da Cabanagem e que quase determinou o fim dessa forma linguística. Apresenta ainda a atual situação da LGA ainda em uso no Amazonas e compara e comenta aspectos fonético-fonológicos, morfológicos, sintáticos e lexicais entre o tupinambá, o tupí e as línguas gerais, com o objetivo de demonstrar as transformações ocorridas de uma fase a outra.

Na sequência, expõe os motivos de não se ter desenvolvido uma língua geral no Nordeste brasileiro e conclui o texto discutindo as possíveis influências fonético-fonológicas e gramaticais do tupí e do tupinambá no português do Brasil, lembrando sempre como é difícil estabelecer com segurança qual delas mais teria contribuído com mais empréstimos para a língua portuguesa. 
Ao final do artigo, o autor apresenta em nota uma breve descrição dos símbolos fonéticos empregados no corpo do texto, seguido de bibliografia básica acerca do tema tratado.

\section{Referências}

Rodrigues, Aryon Dall'Igna. 1986. Línguas brasileiras: para o conhecimento das línguas indigenas. São Paulo: Edições Loyola.

Magalhães, J. V. Couto de. 1876. O selvagem. Rio de Janeiro: Typografia da Reforma. 